\title{
Shifting Aims of Aid to Education
}

\author{
Christian M. DaSilva (University of Ottawa)
}

\begin{abstract}
This paper examines the profound and steady influence of aid and aid modalities on the education agenda in Africa and argues that, ultimately, the broader intent of Education for All as advocated at Jomtien and Dakar was narrowed to an almost singular focus on Universal Primary Education. This narrowing phenomenon is attributed to donor obsession with targets and comes at the expense of true ownership while compromising quality and upstream linkages in the education systems of Tanzania and other African countries. The paper concludes with some of the lessons learned and possible future orientations of aid to education for development.
\end{abstract}

\begin{abstract}
Résumé
Cet article examine l'influence profonde et constante de l'aide et de ses modalités dans l'agenda éducatif en Afrique et soutient qu'en définitive, l'objectif plus général de l'Éducation pour Tous telle que préconisée à Jomtien et à Dakar a été réduit à une quasi-singulière concentration sur l'Éducation Primaire Universelle. Ce rétrécissant phénomène est attribué à l'obsession des bailleurs de fond avec des objectifs et survient au détriment d'une véritable appropriation, tout en compromettant la qualité et les liens réalisés en amont dans les systèmes éducatifs en Tanzanie et d'autres pays africains. Cet article conclue en soulignant quelques-unes des leçons apprises et les possibles orientations futures de l'aide à l'éducation pour le développement.
\end{abstract}

To critically discuss the changing nature of aid to the education sector of developing countries one must address the underlying political context and the effects of diverse ideologies and development paradigms, including the process of globalization and the role of international organizations in shaping and targeting education for development. Situated within these over- arching processes, this paper explores the evolution, variable efficacy, and criticisms of aid to education, as well as some of the many challenges and constraints facing donors, recipients, and intended beneficiaries of education assistance, particularly in Africa. The paper concludes with some of the lessons learned and possible future orientations of aid to education for development.

\section{IDEOLOGY, POLITICS AND DEVELOPMENT PARADIGMS IN OVERVIEW}

The decades-long process of development has brought us to a place where, in most developing countries, school systems serve to signal a "commitment to western-style progress and modernization" (Levinson \& Holland 1996:16) and a willingness to abide by a hegemonic capitalist system. Although challenges to 
modernization theory ${ }^{1}$ have emerged through competing epistemological critiques rooted in post structuralism, post-modernism, and post-colonialism and through alternative development paradigms such as dependency theory ${ }^{2}$ and sustainable development (see Klees, 2008), the modernization/economic growth imperative dominates. Supported by, and increasingly dependent upon, major donors and international financial institutions (Bennell \& Furlong, 1998; Samoff, 1999a), most African countries have little choice but to shape their education systems to support neo-liberal objectives and the parallel global Education For All (EFA) and Millennium Development (MDG) agendas that many argue (Cavanagh \& Mander, 2002, Jones, 2005; King, 2004, 2007; Rose, 2005; Samoff, 1999b; Tikly, 2004) reinforce rather than challenge this paradigm. This tendency reflects belief in what Roger Dale (2000), among others (Carnoy \& Rhoten, 2002), call a common World Educational Culture, which claims universal models of education as evidenced by research showing the extraordinary level of global isomorphism across curriculum categories.

Western socio-economic and political influence in Africa's 'development' are variously linked to historic processes of merchant capitalism (including slavery and plantation economics), colonialism (including the influence of missionaries), and neo-colonialism as well as to the more contemporary processes of modernization, liberal and neo-liberal capitalist penetration and globalization (Ansell, 2005; Bray, 1984; Webster, 1992). Concomitant economic, ideological, linguistic, and cultural influences, including the imposition of incongruous systems of education have brought a new form of imperialism (Tikly, 2004) and the rapid transformation of whole societies. For example, the rapid spread of English in Africa laid the foundation for a functionalist argument based around the inevitability, global reach, and natural affinity of English to the inherited school system (see Mazrui, 2004; 40)

Punctuated by world events (two World Wars, a protracted Cold War, economic recessions \& expansions among others), African development has been historically determined by forces outside the continent.

\footnotetext{
${ }^{1}$ Based on classic work by Durkheim (1858-1917) and Weber (1864-1920), modernization theory was advanced by American scholars such as Talcott Parsons in the 1950s and 60s. Hostile to customs and tradition, modernization theory favoured rationality and the replacement of primitive values by modern ones (see Webster, 1992). In comparative education, modernization was based on an epistemology of positivist functionalism (see Welch, 1985, 1993, 1999).

${ }^{2}$ In contrast to modernization theory, the work of Marx (1818-1883) forms the basis of three theories of underdevelopment. In these, the developing world has been historically and repeatedly exploited through either economic imperialism (Lenin, 1966), client-patron relationships between the metropolitan centre (former colony) and third world elites working in complicity (dependency theory, see Frank, 1981), or as a result of urban bias (Lipton, 1977) where city-based elites siphon off development aid and distort national policy to favour themselves over rural poor.
} 
In the 1950s and 60s, economic and institutional functionalism and western knowledge combined, despite post-colonial resistance to both (Bhabha, 2001; Bhola, 2002; DaSilva, 1995; Odora-Hoppers, 2002; Reagan \& Mahwah 2000; Welch, 1985), to advance the persuasive arguments of the modernization paradigm. Influenced by the Marshall plan, post-war modernization in development discourse was relentlessly promoted with education increasingly proposed as the central investment (Farrell, 1999), the provision of which promised positive, western-style growth. In fact, the idea of education for economic development "achieved almost paradigmatic status in modernization literature of the post-war era" (Welch, 1985:13). Appropriately skilled labour was seen as the 'capital' or missing ingredient situating "education even more squarely in the centre of this optimistic vision" (Ibid, p.150). By mimicking and expanding broad-based access to the type of educational opportunities enjoyed by Europe and North America, it was thought the natural conditions for economic 'take-off' ${ }^{3}$ could be quickly re-created.

Through the 1970s and early 1980s, economies were stalled and the massive investments in human capital ${ }^{4}$ were "under siege with neo-liberals gaining ground" (Tabulawa, 2003:15). Constraints to modernization theory's optimistic 'recipe' were emerging. Population growth outpaced educational expansion, educational reforms were only partially implemented, and serious urban/rural, gender, and class divisions were exposed for the first time. In this post oil-shock period of economic recession and rising neo-conservatism, conditions were set for a new paradigm based on liberal democracy and free market solutions. With Reagan's attacks on the state as "part of the problem", a purified market-based version of the growth paradigm emerged and the profoundly ideological 'Washington Consensus' in development began. Interestingly, Nordtveit (2008) talks about an emerging "Beijing Consensus" marked by both a dramatic increase in African students studying in China and by increased Chinese aid to the education sector of African countries.

The rigid structural adjustment programs (SAPs) that characterized this period were gradually supplanted by the discourse of globalization (De Moura Castro, 2002; Jones, 1998) though the uncritical adoption of neo-liberal macroeconomic policies persist today as preconditions for Official Development

\footnotetext{
${ }^{3}$ Linked to the socio-psychological analysis in modernization theory of transition from traditional to modern society, this term is part of Rostow's (1960) seminal work Stages of Economic Growth: A Non-Communist Manifesto in which he argues all societies can be situated in one of five stages;1) traditional 2) preconditions for take-off, 3) take-off 4) drive to maturity 5) age of high mass consumption.

${ }^{4}$ A seminal work in this area is Harbison \& Meyers (1964) - Education, Manpower and Economic Growth, in which human resources were seen as a form of capital, a product of 'investment' and a vital ingredient in economic development (see Welch, 1985:13).
} 
Assistance (ODA). Structural adjustment under the leadership of the IMF and World Bank typically included massive social sector cuts as well as taxation, fiscal, and monetary policy more typical of fully developed economies. One of the most serious implications of structural adjustment policies was the spread of privatization of education (Colclough, 1996; Whitty \& Power, 2000). As a result, the rhetoric of participation and ownership now forges a tenuous, suspicion-filled alliance between international financial institutions, donors and western NGOs whose quest is to transform African nations in their own image with the aim of establishing a global consensus for neo-liberal systems of economic and political management while "legitimating the increasingly intrusive supervision of African political communities by northern actors" (Takyi-Amoako, 2008:52).

\section{SHIFTING AIMS AND WORLD BANK INFLUENCE}

The profound ideological influence of multi-lateral institutions, particularly the World Bank (hereafter called the Bank), its interconnectedness with the neo liberal agenda described above, and its ability to attract criticism for its effects on aid to education warrants a separate discussion. Few institutions could counteract the Bank's policy influence, as even organizations like UNESCO were heavily reliant on the Bank for funding. UNESCO's cooperative program, for example, was $75 \%$ financed by the Bank. Bank policy has not only changed emphasis over time, it has caused wholesale paradigm-shifts in the philosophical direction and delivery mechanisms of aid to the education sector of developing countries. The Bank has tended to become 'captured' by single methodologies, especially manpower forecasting and rate of return techniques (Bennell, 1996a, 1996b; Heyneman, 2003). Unflinchingly rooted in an economistic, human capital framework true to its governing principles as a bank, its influence can be seen in three linked but distinct phases.

The first includes that period when the Bank's attention turned from post-war reconstruction of European infrastructure to the problem of non-existent infrastructure in developing countries. Education-related investments were made on the basis of manpower projections for specific sector projects ${ }^{5}$ in agriculture, engineering and the like, conceived of in terms of their contribution to raising GNP. In this context, the Bank and other agencies supported a range of projects to expand the skills base of low-income countries designed to "kick-start the industrialization process" (Tikly, 2004: 189). The implication of this approach was its bias against other parts of the education sector. In fact, the Bank's lending

\footnotetext{
${ }^{5}$ The concern was for the Bank's investment in a specific sector project and the fear that a lack of agricultural engineers, for example, would put in jeopardy the success of a new fertilizer manufacturing plant (Heyman, 2006).
} 
program at the time prohibited any assistance to primary and academic secondary education sectors. It was even prohibited from supporting libraries (Heynemann, 2003:317). Alternatives to the 'practical' education assumptions were dismissed in favour of technical (vocational) training seen as more useful for Bank projects and the labour market.

A second phase emerged in the 1970's and continued through to the early 1990's when the present focus on basic education took hold. During this period, it was believed that there was a surplus of general skills (literacy, numeracy) and an unmet demand of specific job-related skills. The solution was a 're-orientation of the [secondary school] curriculum from top to bottom so as to "ensure that graduates [could] be employed" (Heyneman, 2003:318). Quality improvements were synonymous with making education "more practical and relevant by reorienting the content away from academic and toward vocational purposes" (Ibid, p.318). At the same time, another paradigm shift was forming within the Bank. Increasingly, the widely used ${ }^{6}$ economic concepts of 'rate of return' (RoR) began to infiltrate the thinking of the Bank's Education Department and, inspired by the first RoR reports on education in India and Malawi, a slow, steady re-focusing of Bank investments toward basic education began. Accelerated in the 1980s by the fiscal doctrine of structural adjustment, RoR methodology "led to greater and clearer justification for primary education" (Ibid, p.324) and withdrawal from other forms of education (secondary and tertiary levels). This emphasis was contained in the Bank's new "short policy" which included 1) a shift away from vocational and higher education toward academic and basic education, 2) increasing the private cost of university, 3) installing loan schemes to offset the increased fees for higher education (Colclough, 1996).

Since the fall of the Berlin Wall, the Bank and its allies in the donor community have demonstrated a remarkable convergence of ideology and practice (King, 1991, 1992; Klees, 2001; Samoff, 1996; Smith, 2005). The influence on practice is reflected in new aid modalities (such as Sector Wide Approaches or SWAPs, and Direct or General Budget Support - DBS/GBS) as well as a strong, neo-liberal inspired push for decentralization, efficiency and accountability in education reform. In Tanzania, for example, donor support for education reform, either through sector budget support or through General Budget support (most donors) is predicated on decentralization of most decisionmaking authority to local governments that are woefully unprepared for the task. The ideological convergence underpinned by these aid modalities can be seen in

\footnotetext{
${ }^{6}$ Rate of Return analysis was commonplace for virtually all other aspects of Bank analysis and lending programs (Bennell, 1996b; Burnett, 1996).
} 
the development and constriction of the EFA and MDG agendas ${ }^{7}$ so important in aid/education discourse today. The next section deals with this EFA/MDG phenomenon first.

\section{BUILDING THE EFA/MDG 'CONSENSUS'}

Through an iterative and near-synchronous process ideologically led by the multilateral community, many have traced the 'donor-centric' construction of the current EFA agenda (for example, Colclough, 2005; Jansen, 2005; King, 2007). The construction of a global consensus is traceable through a series of regional and global $^{8}$ education conferences, most notably the 1990 World Conference on EFA held in Thailand. Known simply as Jomtien, the conference marked the beginning of a formal push toward EFA - an idea captured at the time in a broad declaration that included non-formal, informal, apprenticeship, early childhood, secondary, university and adult as well as primary education. However, the EFA and MDG agendas that determine aid to education policy today are much narrower versions of the Jomtien ideal. What follows is a brief synthesis of how and why this occurred and what it means for the sector.

UNESCO, along with the World Bank, UNDP and UNICEF, was one of four sponsoring agencies for Jomtien and brought the longest history and broadest perspective in the field of education. As the ostensible lead, the resultant declaration focusing on basic education in the broadest sense could have been predicted. However, primary education was the only part of the basic education thrust linked to a time bound target of the year 2000 and both UNICEF and the World Bank, reflecting their devotion to RoR methodology, had made it clear that, regardless of the broader scope articulated for basic education, they wished to focus their efforts and resources on primary education (King, 2007). In 1996, midway between Jomtien and the declaration's 10-year review at Dakar, the OECD-DAC entered the discourse in a very influential way. Through a process established to review lessons learned and progress achieved at previous development conferences, the DAC created its International Development Targets (IDTs), two of which addressed education; one calling for universal access to primary education by 2015 (arbitrarily moving the target established at

\footnotetext{
${ }^{7}$ This is a process that Weiler (1984. see also Klees, 2008) calls "compensatory legitimation" and provides another way of viewing the global effort toward EFA. This process requires our multi/bi-lateral systems to "introduce policies [like] EFA and the MDGs aimed at ameliorating problematic conditions" created by globalization and, in so doing, "restore a degree of legitimacy". Put another way, the World Bank and others have attempted to ground themselves in the gentler "logic of internationalism" in response to their own complicity in the harsher realities of globalization ${ }^{7}$ (Jones, 1998).

${ }^{8}$ Most notable are the region-specific conferences in Santiago (1962), Karachi (1960), Addis Ababa (1961), where plans and priorities were regionally tailored, and the global conferences at Jomtien (1990), Dakar (2000), the IDTs, and the MDGs where a universal notion around education took shape.
} 
Jomtien), the second for an end to gender disparity at all levels by 2005 (Ibid). The IDTs effectively reduced Jomtien's ambitious EFA agenda to a near singular focus on Universal Primary Education (UPE), based not only on the perceived lack of progress and the need to accelerate it, but also by the increasing desire to measure results.

By Dakar, the mediocre progress on Jomtien and the influence of the IDTs led to new target dates (2015 to align with DAC) and a renewed commitment from donors (exemplified by the creation of the global fast track initiative or GFTI) to a simpler and narrower emphasis on primary education and gender equality. However, Dakar did also see UNESCO return to "reinforce the wider understanding of basic education...present at Jomtien which the DAC [IDTs] had shrunk to just two items"(Ibid, p.384). In so doing, the Dakar framework restated much of the original Jomtien declaration, yet, despite this effort, a discernible pattern was emerging where appeals to respect the broader framework of Jomtien and Dakar would continue to be subsumed by target setting and outcome measurement, effectively reducing EFA, once again, to UPE for all (Samoff, 1999a, 1999b; Rose, 2005). Buoyed by the unprecedented unanimity around EFA (at least in the donor community), and motivated by the arrival of the millennium, two education targets virtually identical to the education-related IDTs were included as UN Millennium Development Goals (MDGs). It is difficult today to find a major bilateral, multilateral or nongovernmental organization ${ }^{9}$, which does not place the narrow, target-driven EFA and MDG education goals at the centre of their own strategic plans ${ }^{10}$.

However, it is important to consider how, in this narrowing process, so much was 'lost in translation'. In discussing this, King (2007) shows, for example, how the broader text of the Jomtien Framework stressed the highly country specific approaches needed to implement EFA rather than a one size fits all approach. Similarly, the larger DAC report contains strong references to national self-reliance and country ownership yet it is the 6 , digestible IDTs that are coveted, recycled, and repeated. Finally, King points out that while the Millennium Declaration, with its broad set of resolutions, was approved by the summit delegates, the declaration was only distilled into 8 MDGs, 18 targets, and 48 indicators by the UN Bureaucracy months later (p.380-386).

This disconnect between emancipatory rhetoric and measurable reality is described by Maclure and Levan (2008), among others (Ansell, 2005; Samoff,

\footnotetext{
${ }^{9}$ Largely shut out of these government-sponsored initiatives, NGOs have carved out their own space in education. For example, a broad coalition of NGOs and teacher unions developed their own parallel framework for action known as the Global Campaign for Education (see Mundy \& Murphy, 2001).

${ }^{10}$ As an employee of a bilateral donor I am both impressed and astounded at the concentration exerted on the relatively new global mandates like the MDGs, the Paris Principals on Aid Effectiveness and EFA.
} 
2007; Smith, 2005) as a dialectic alternating over time between a view of education for development rooted in a utilitarian, modernization paradigm and one based optimistically on the transformative, emancipatory power of the educational process per se. The latter has enjoyed periodic but short-lived resurgences, most notably around the enthusiastic periphery of the aforementioned global conferences. Yet, EFA and the MDG's, supported by the GFTI and the new aid modalities of SWAPs and DBS / GBS demonstrate a profound convergence of opinion by donors that basic education, with an appreciation for the unique challenges faced by girls, is the foundation of national development, reduced poverty, improved employment prospects and better living standards. The utilitarian model of education prevails, reinforced by new aid modalities to which the paper now turns.

\section{AID MODALITIES, CONDITIONALITY AND DEPENDENCE}

Enthusiasm within donor organizations suggests we have left the 'stone age' of development, where bilateral donor-led projects and technical assistance were axiomatic, for a new era of focused, efficient, and coordinated efforts between donors and recipients working toward common goals. The 2005 Paris Declaration on Aid Effectiveness represented a sea change in the business of delivering development assistance, the mechanisms of which are still being developed and the ramifications of which are only now beginning to be examined.

Many question whose goals are driving the new aid effectiveness agenda and for what purpose. Some argue that the advent of new aid modalities serve to re-colonize education under the guise of local/national ownership, design, oversight, and implementation. Aid modalities can be understood on a continuum of donor conditionality and control starting with bilateral projects as the most 'primitive' modality and general or direct budget support as the most 'advanced'. Earmarked sector - based support falls roughly in the middle. As one moves toward GBS, donors lose direct control over funds though donors exert considerable control over the plans and measurement frameworks that lead to and govern sector or general budget support. That said, many are asking whether sector-wide planning and the emphasis on targets attached to donor funds has overwhelmed the need for school-level planning and input entirely (Klees, 2001, Foster, 2000, Samoff, 2003, among others).

National Governments agreed, under the Paris paradigm, to produce National Poverty Reduction Strategies as a condition of aid and to demonstrate ownership of the development agenda. This extends to sectors, including education, but the influence of the donors in the review and approval of these 
national and, especially, sector level plans is profound. Performance is scored and subsequent aid tranches often-conditional meaning donors still have a firm hand on the wheel.

Leading the new aid modalities 'era' is the World Bank and Klees (2001), among others, (Colclough, 2005; Heyneman, 2003; King, 2003, 2004; Samoff, 2003; Smith, 2005) believes that the co-opting of the term 'partnership' and the omnipresent use of holistic, participatory language is little more than SAPs dressed like SWAPs. The myriad of complex conditions and the adherence to the deceivingly simple targets of the MDG/EFA goals force recipient governments to suppress local, grassroots responses to educational challenges in favour of quantifiable and measurable growth (such as gross enrolments), needed to oil the ODA machinery. The ubiquitous nature of these new partnerships also serves to silence many previously vocal critics of the Bank in the pre-SWAP era, including many bilateral donors now working in a "harmonized" post Paris Declaration environment hand in hand with the Bank.

With respect to General or direct budget support (GBS/DBS), Yamamoto (2007) finds this aid modality "unfriendly to decentralization" (p.101) because it requires high-level policy dialogue and is designed foremost to strengthen the recipient state and its core functions rather than the target (education) sector. While funding flows through central government does strengthen financial ownership, it can decrease service delivery at the school level. Experience globally shows that government bureaucracies delay and 'tax' the flow of funds as they pass through various administrative layers. As a result, what has been promoted as 'best practice' at the central level has, so far, proven far less empowering at the local level (Smith, 2005). With GBS/DBS, national ministries of finance trump line ministries at donor tables leaving sector-specific concerns largely unaddressed. In addition, despite the fact that donors increasingly favour this aid modality, the strict requirements for results based management, better accountability mechanisms, good governance, and high-level policy engagement mean local input is marginalized and the poorest countries are left on the outside looking in. As GBS/DBS is invariably structured within multi-donor agreements, individual donor responsibility for failures (or successes) is diluted thereby weakening incentives for close engagement and sector improvement. What is more, the government-to-government nature of new aid modalities has left NonGovernmental Organizations (NGOs), and most efforts to strengthen civil society, increasingly marginalized ${ }^{11}$ (Mundy \& Murphy, 2001).

\footnotetext{
${ }^{11}$ One of the key criticisms of the Paris Declaration on Aid Effectiveness is that it did not consider, let alone apply to, the role of NGOs, yet the declaration is central to donor strategies and changing models of aid delivery.
} 
One instrument supporting these aid trends is the Global Fast Track Initiative (GFTI). As an enhanced aid modality, the GFTI has mobilized additional technical and financial resources for eligible countries committed to EFA; however, Bank control of the secretariat has influenced the key benchmarks toward the primary schooling targets of the MDGs, effectively ignoring the broader EFA goals discussed earlier (King, 2007). In addition, NGOs have "voiced concern over lack of process, participation, and ownership" (Rose, 2005; 383) asserting that claims of national ownership are misplaced as countries must implement a blueprint of 'indicative UPE benchmarks' even when these do not fit with country-owned education plans. Stringent requirements (like poverty reduction and education strategies) are criteria clearly biased in favour of 'donor darlings' and against recipients furthest from achieving UPE targets. DFID in particular has voiced concern that a number of the countries selected for the GFTI are already 'over-aided' and has campaigned for an Analytical Fast Track as part of the GFTI with modest success (King \& Rose, 2005; Rose, 2004). Finally, the GFTI seriously undermines the concern for quality education by seeking to reduce the unit costs of primary education through measures such as capping of teacher salaries (Verger, 2008:146). While new aid modalities impact national ownership and the quality of education, the increasingly dominant global consensus also increases aid dependency. Aid flows, and the donor determination which attend them, lack fixed timelines leading some to worry (see King, 2004) that ambitious targets without an aid withdrawal plan is nothing short of planned dependency and further evidence of a re-colonization through aid.

This paper has thus far explored the impact of various ideological, historical and institutional factors on the provision of basic - meaning primary -education; however, some (King, 2003; Malholtra, 2000; Samoff, 1996) question the emphasis on UPE itself as the central issue. First, many children will simply not be able to take advantage of basic primary education when it is offered due to lack of household resources or by being on the wrong side of the opportunitycost calculation of poor families where at least four key factors negatively impact school attendance: the direct cost of schooling being too high; child labour is required by the household; insufficient school spaces are available and; low quality of schooling on offer. The dire situation for girls is further exacerbated by gender roles in societies that "change the balance of incentives for girls and boys to attend school" (Colclough et al, 2000:7). Second, frustration is mounting among post-primary school-leavers searching for coherent pathways to employment or further training. With the economic downturn in the 1980s, nonformal education became less viable as part of socio-economic development strategies owing..."to a shift to schooling as a priority and the pulling back of 
governments from social service funding" (Labelle, 2000: 21). Calls for a broader consideration of alternate pathways such as non-formal education (Labelle, 2000) and skills training (King, 2007) are, however, becoming more frequent and urgent as numbers of primary school leavers swell. In addition, poor quality primary education is widespread. One finds frustration where gains made in expanding UPE are threatened by families reconsidering the poor economic returns on their investment in basic education and weakening resolve to make similar choices for younger siblings. Unchecked this dynamic could reverse the much-trumpeted gains in universal primary education.

\section{TARGETING, QUALITY \& QUANTITY}

EFA and the MDGs specify targets to be met, and the measurement machinery (marketed as progress), has overtaken other evidence of tangible successes in improving children's education (Kuder, 2004; Norman, 2004). While Jomtien and Dakar embraced broad interpretations of EFA including a focus on quality, only the most measurable targets were taken as the basis for the Millennium Development Goals (Colclough, 2005). Donors use these global targets in domestic accountability frameworks ${ }^{12}$ while recipients, in what Norman (2004) terms incentive compatibility, dutifully incorporate these targets to meet complex conditionalities of World Bank approved Poverty Reduction Strategies (PRS) and donor-funded national education plans. In fact, where the purpose of education reform is defined in terms of meeting a few simple targets, incentives to falsify data relating to those targets can emerge (Norman, 2004:46).

The poor and declining quality of UPE causes school completion rates in most of Africa to lag far behind enrolment (Samoff, 2007): the difficult-tomeasure Dakar targets on quality remain eclipsed by the simple enrolment focus left over from the EFA decade.

There is considerable evidence to show that the quality of basic education is more important than the quantity and that quality is directly related to the degree to which local learning objectives and practices, as well as the relationship between teachers and learners are respected and developed (Samoff, 2007). Facing numerous systemic constraints such as shortages within their ranks, poor pay and training, inadequate infrastructure, poor mobility, professional isolation and the weight of often unrealistic expectations (Avalos, 2000, Jennings, 2001, Welmond, 2002, Villegas- Reimers and Reimers, 1996) teachers are "nevertheless placed at the uncomfortable intersection of contradictory demands made on education systems" (Welmond, 2002:37) the

\footnotetext{
${ }^{12}$ DFID's agreement with the UK Treasury requires simple enrolment increases in 16 recipient countries as the key performance measure.
} 
world over, yet their role in the quality of education discourse cannot be overstated. These issues are interrelated as low status, poor working conditions, and salaries for teachers exacerbate shortages. Welmond (2002), for example, provides evidence from "16 African countries with high indebtedness and negative economic growth" (p.41) where teacher salaries were decreased through the 1980s and 1990s.

Pedagogy is a problem in African schools with critics often citing an over-reliance on rote learning and 'teaching to the exam'. Some point to the reliance on exam results as the proxy for quality and blame the pressure for results demanded by the new aid orthodoxy for poor student achievement (Kiernan, 2004). In addition, much needed curriculum reform is often stalled by lack of local involvement or imported with little local ownership (DaSilva, 1995). While some argue vociferously against cultural relativism (Craig, 2007) and others for the possibility of a world educational culture (Carnoy \& Rhoten, 2002; Dale 2000), others assert that "there are not and cannot be universal best practices"(Samoff, 2007:490) in pedagogy or curriculum reform. Ultimately, some space needs to be reserved for local innovation, not because local is necessarily best - although occasionally it is - but because these innovations are a proxy for ownership and engagement by teachers and can contribute positively to improved methods, content and quality of education more generally. For example, in many districts in Tanzania (Biharamulo, Lindi, Chato, Mpanda, Mbeya, Moshi rural and others), experienced teachers (subject experts) volunteer to assist other teachers within their ward/district with innovative teaching methods. In science, for example, subject experts use local products such as tomatoes and lemons to demonstrate acidity. They do this without remuneration providing a cost saving for both teachers and the government while at the same time improving performance in respective subjects.

Donors are, however, overly reliant on their own domestic research or World Bank consultants. Samoff (1999a) for example, points to an extensive review of some 240 studies and reports completed between 1990-94 on the education sectors of sub-Saharan Africa and the convergent, neo-liberal recommendations they contain ${ }^{13}$. Rather than resist donor expertise or jeopardize aid flows, national education strategies tend to accept western pedagogical best practice, such as child-centered learning. Tabulawa $(2003,1997)$ has found that this widespread importation of pedagogy brings with it a subtle, yet pervasive, ideology driven by ideas of liberal democracy and capitalism, beliefs that are part

\footnotetext{
${ }^{13}$ Typical recommendations include reducing the role of the central government, decentralizing, increasing school fees, assisting private schools, introducing double shift and multi-grade classrooms among others (Samoff, 1999:250).
} 
of a "hidden agenda...aim[ed] at inculcating affective, moral and philosophical values about desirable psycho-sociological traits for individuals and for society" (p. 10). He accuses this pedagogy of being "part of a wider design...to facilitate the penetration of capitalist ideology in periphery ${ }^{14}$ states...under the guise of democratization" (p. 10).

\section{PRIVATIZATION}

The growing cost of providing universal primary education coupled with a neoliberal preference for the marketplace over perceived corrupt and bureaucratic public systems has, since the 1980s, helped advance privatization as a policy prescription. Tuition fees and cost recovery for books, supplies, and uniforms have been variously introduced to help meet the financial burden of education provision and the demand side issues of choice and opportunity ${ }^{15}$. Though privatization policies are being revisited and in some cases reversed, the 'hangover' from the structural adjustment era poses challenges. Most (Colclough, 1996, Adnett, 2004; Daun, 2000; Whitty \& Power, 2000) have found aspects of the privatization of schooling ${ }^{16}$ wanting, arguing, for example, that the extension of private schooling over time threatens the ability of societies to transfer resources to support the schooling of children from lower income groups and decreases access to primary education for poor children and girls. In contrast, some in the privatization camp argue, "the indifferent performance of the reforms so far is merely evidence that they have not gone far enough (Whitty \& Power, 2000:103).

\section{GIRLS' EDUCATION}

Girl's education remains a concern. While primary school enrolment has generally increased for both boys and girls, aggregate gender gaps in enrolment persists in all developing regions. This means that enrolment for girls is still more than $10 \%$ lower than boys.

14 Tabulawa (2003) uses a world systems framework in his paper, which posits that the USA, Western Europe, and Japan constitute a 'core' zone while less industrialized nations are relegated to the periphery (p. 11).

15 Mundy and Murphy (2001) say "from the mid-1980s, debates about education...were increasingly characterized by a new interest in such issues as privatization, public choice [and] decentralization..."(p.98).

${ }^{16}$ Colclough (1996) analyses several neo-liberal prescriptions for education including fees at the primary, secondary and tertiary levels, loans and scholarships, private education and alternative measures (like using taxation or a graduate payroll tax). He concludes that fees at primary and secondary are generally counter productive while at the tertiary level they may have some utility if access to poorer students can be assured in other ways, such as through bursaries. 
Although expressed as targets in both the EFA and MDG agendas, progress has been inconsistent. There is an important distinction between EFA and the MDGs in this regard. The Dakar framework is much more ambitious calling for gender equality (which implies addressing power relations between men and women) while the MDG target on gender simply calls for gender parity in schooling - a target more easily obtained through equal enrolment of girls without concern for their outcomes (see Colclough, 2005).

Most researchers agree that poverty itself necessitates an opportunitycost analysis by poor families (Colclough, Rose \& Tembon, 2000, Leach: 2000, Mickelson: 2001, Stromquist: 1998) and that families often choose to invest in boys over girls. Some, (Colclough, Rose and Tembon (2000)) argue that gender disparity in schooling has more to do with cultural practice than with poverty. Others (Leach: 2000, Stromquist: 1998) look at the shortcomings of national or international institutional approaches to gender equity for a discernable cause and effect. Leach (2000), blames the macro-level policies of donors and NGOs, saying that their approaches are narrow and simplistic (p.333). Stromquist (1998) says, "the institutional and cultural framework that sustains gender asymmetries in society is essentially undisturbed" (p. 99). With respect to aid modalities, the decentralization trends being promoted may have negative consequences for girls in poor areas (Stromquist, 1998). Decentralized services for girls may simply not happen when this "provision is to be met from local revenues" (p.337). Stromquist also has concerns where decentralized control is expressed more traditionally, such as in the provision of training of women for domestic roles, saying that school-heads and teachers with greater autonomy "are unlikely to be ardent supporters of broadening female pupil's horizons beyond early marriage and childrearing into higher education and careers" (Ibid, p. 338). Despite the global focus on improving girls' education through the EFA and MDG targets, societal and systemic constraints have thus far proved too great for improvements to be realized.

\section{LESSONS LEARNED AND FUTURE DIRECTIONS}

Many issues are raised in this paper including challenges posed by dominant actors and the global consensus around education itself. The narrowness and negative consequences of targets, the lack of post-primary options, and problems of quality related to teacher satisfaction, inappropriate curricula and pedagogy are all problematic. Finally, the restrictive if more generous aid modalities threaten local ownership and engagement while increasing the likelihood of aid dependency. 
It is difficult to avoid discussion of the Asian Tigers when considering lessons learned and ways forward. Green et al (2007) among others (Heyneman \& Todoric-Bebic, 2000; McGinn, 2005; Morris, 1996) argue that while geopolitical advantage and fortuitous timing vis-à-vis industrialization were the 'tigers' good fortune, there are policies and programs that may be worth replicating. States should, for example, invest in high quality education to bring marginalized and rural populations within the mainstream of national development. In this regard, African and other countries pursuing UPE, whether willingly, compliantly, or both are perhaps on the right track.

Upgrading the skills base (through expanded secondary, technical and higher education) in a sequential manner linked to each successive economic shift to higher value-added economic activity is critical, especially given the high numbers of post-primary students looking for opportunities. Here Green and Little's observations join with King \& Rose, (2005) to find troubling gaps in the post-primary space. Heyman (2006) for example, notes that in Rwanda and Kenya, education policy is pushing beyond the primary level with a view to creating knowledge-based economies by 2012 and 2020 respectively. Some have characterized the over-emphasis on primary education, influenced strongly by World Bank return on investment methods, as "a ploy and even as a capitalist conspiracy to see that developing countries ...remain under-developed educationally as well as economically" (Tilak, 2007:85). The narrow focus on primary education needs to be actively contested. Fortunately, the Bank and other donors are starting to show increasing interest in secondary and technical and vocational training again.

There is a need to develop communication skills to facilitate international transactions, a measure given new meaning by the recent and rapid rise of China and India as resource-hungry economic powers increasingly involved in Africa. In addition, most analyses of the Asian Tigers emphasize the successful formation of social capital based on "traditional endogenous values and practices rather than the modern best practices proposed from the outside" (McGinn, 2005:23). Finding ways to value local knowledge and learning methods may help improve the quality of education while adding a stronger sense of local and national self-determination. Finally, the aid relationship needs further analysis and critique. As an employee of a donor organization, I believe people generally serve with a sense of mission and a desire to do positive things. However, the powerful influences of the global education agendas and aid modalities raised here and elsewhere in the literature strongly suggest we proceed with caution and with a willingness to examine our assumptions and practices critically - and change them as necessary. 


\section{References}

Adnett, N. (2004), Private-sector Provision of Schooling: An economic assessment, Comparative Education, 40 (3), pp. $385-400$.

Ansell, N. (2005). Children, youth, and development. New York: Routledge.

Avalos, B. (2000). Policies for Teacher Education in Developing Countries. International Journal of Educational Research, 33 (5), pp. 457 - 74.

Bennell, P. \& Furlong, D. (1998). Has Jomtien Made any Difference? Trends in Donor Funding for Education and Basic Education Since the Late 1980s. World Development, 26 (10), 45 - 59.

Bennell, Paul (1996a). Rates of Return to Education: Does the Conventional Pattern Prevail in Sub-Saharan Africa? World Development 24 (1): 183-99.

Bennell, P. (1996b). Using and Abusing Rates of Return: A Critique of the World Bank's 1995 Education Sector Review. International Journal of Educational Development 16(3): 235-48.

Bhabha, H.K., "Unsatisfied: Notes on Vernacular Cosmopolitanism" in Postcolonial Discourses; An Anthology, Castle, G. (ed), 2001, pp. 38-52

Bhola, H.S., (2002). Reclaiming Old Heritage for Proclaiming Future History; The Knowledge-forDevelopment Debate in African Contexts. Africa Today, 49 (3), 3-21.

Bray, M. (1984). International influences on African educational development, International Journal of Educational Development, 4 (2), 129-136.

Burnett, N., (1996). Priorities and Strategies for Education - A World Bank Review: The Process and the Key Messages. International Journal Of Educational Development 16 (3), 215-220.

Carnoy, M., and Rhoten, D. (2002). What Does Globalization Mean for Educational Change? A Comparative Approach. Comparative Education Review, 46 (1), 1-11.

De Moura Castro (2002). The World Bank Policies: Damned if you do, damned if you don't. Comparative Education, 38 (4), 387 - 399.

Cavanagh, J., \& Mander, J. (Eds.). (2002). Alternatives to globalization: A better world is possible. San Francisco: Berrett-Koehler.

Colclough, C. (2005), Rights, Goals and targets: How do Those for Education Add Up? Journal of International Development, $17101-111$.

Colclough, C., Rose, P., \& Tembon, M. (2000). Gender inequalities in primary schooling: the roles of poverty and adverse cultural practice. International Journal of Educational Development, 20, 5 - 27.

Colclough, C. (1996). Education and the Market: Which Parts of the Neo-liberal Solution are Correct?, World Development, 24 (4), $589-610$.

Craig, A. P. (2007). How Cultural Differences Shape the Perception of Knowledge: A Psychology of Learning and Teaching for Democratic Societies. Lewiston: The Edwin Mellen Press.

Crawford, G. (1995). Promoting Democracy, Human Rights and Good Governance Through Development Aid: a comparative study of the policies of four northern donors. Working Papers on Democratization. Centre for Democratization Studies, University of Leeds.

Dale, R. (2000). Globalization and education: Demonstrating a "common world educational culture" or locating a "globally structured educational agenda"? Educational Theory, 50 (4), 427-448.

DaSilva, C. (1995). Divergence or convergence: local environmental knowledge, secondary schools, and environmental education in Tanzania. Unpublished M.A. Thesis, Carleton University, Ottawa.

Daun, H. (2000). Primary Education in Sub-Saharan Africa: A Moral Issue, an Economic Matter, or Both?, Comparative Education, 36 (1), pp. 37 - 55.

De Moura Castro (2002). The World Bank Policies: Damned if you do, damned if you don't. Comparative Education, 38 (4), 387 - 399.

Farrell, J. P. (1999). Changing Conceptions of Equality of Education: Forty years of comparative evidence. In Arnove, R. F., \& Torres, C. A. (Eds.). Comparative Education: The Dialectic of the Global and the Local. Lanham, MD: Rowman \& Littlefield Publishers.

Foster, M. (2000). New approaches to development cooperation: What can we learn from experience with implementing sector wide approaches? Working Paper, No. 140. London: Overseas Development Institute. 
Frank, A.G., (1981). Crisis: In the Third World. Monthly Review Press, New York.Green, A., Little, A., Kamat, S., Oketch, M., \& Vickers, E. (2007). Education and development in a global era: Strategies for successful globalization. Researching the Issues series, 69. London: DFID

Harbison, F., and Myers, H., (1964). Education, manpower, and economic growth: strategies of human resource development. McGraw-Hill. New York.

Heyman, R. (2006). Are the MDGs enough? Donor perspectives and recipient visions of education and poverty reduction in Rwanda. Norrag News, (37), 35-37.

Heyneman, S. P. (2003). The history and problems in the making of education policy at the World Bank 19602000. International Journal of Educational Development, 23, 315.

Heynemann, S. P., \& Todoric-Bebic, S. (2000). A Renewed Sense for the Purposes of Schooling: The Challenges of Education and Social Cohesion in Asia, Africa, Latin America, Europe and Central Asia. Prospects, 30 (2), $145-67$.

Jansen, J. D. (2005). Targeting education: The politics of performance and the prospects of 'education for all'. International Journal of Educational Development, 25, 368.

Jennings, Z. (2001). Teacher Education in Selected Countries in the Commonwealth Caribbean: The ideal of policy versus the reality of practice. Comparative Education, 37 (1), 135 - 142.

Jones, G. (2005). Children and development: Rights, globalization and poverty. Progress in Development Studies, 5(4), 336-337-342.

Jones, P. W. (1998). Globalisation and Internationalism: Democratic prospects for world education, Comparative Education, 34 (2), pp. 143 - 155.

Kiernan, M. (2004). Targets for minimum quality basic education - can we define minimum quality, provide it, measure it and compare it? Or, can one fast track quality. Norrag News, 33, 44.

King, K. (2007). Multilateral agencies in the construction of the global agenda on Education. Comparative Education 43(3): 377 - 391.

King, K. (2004). The External Agenda of Educational Reform: A Challenge to Educational Self-Reliance and Dependency in Sub-Saharan Africa in Journal of International Cooperation in Education, 7, (1), 8596

King, K. (2003). Global targets, local realities: Rethinking Education and Training for Development. Orbit, Voluntary Service Overseas.

King, K. (1992). The external agenda of aid in internal educational reform. International Journal of Educational Development, 12 (4), 257-263.

King, K. (1991) Aid and Education in the Developing World: the role of the donor agencies in educational analysis. Essex: Longman.

King, K., \& Rose, P. (2005). International development targets and education: Towards a new international compact or a new conditionality? Journal of International Development, 17, 97.

Klees, S. (2008). Growth, development, EFA, and MDGs. Norrag News, 40, 50-51,52.

Klees, S. J. (2001). World Bank Development Policy: A SAP in SWAP's Clothing. Current Issues in Comparative Education, 3(2): 1-11.

Kuder, J. (2004). UPE in Tanzania: Swapping quality for quantity - again? Norrag News, 33, 52.

Labelle, T. J. (2000). The Changing Nature of Non-formal Education in Latin America. Comparative Education, 36 (1), pp. $21-36$.

Leach, F. (2000). Gender implications of development agency policies on education and training, International Journal of Educational Development, 20, 333 - 347.

Lenin, V.I., (1966). Imperialism, The Highest Stage of Capitalism. Moscow: Progress Publishers.

Levinson \& Holland, B. A., (1996). The Cultural Production of the Educated Person. In B. A. Levinson \& Holland, D. E. Foley, \& D. C. Holland (Eds.) The Cultural Production of the Educated Person: Critical ethnographies of schooling and local practice. Albany, NY: SUNY Press.

Lipton, M., (1977). Why Poor People Stay Poor. London: Temple Smith.

Maclure., R., Lavan, D., \& Sabbah R. (2008). Education and Development: The Perennial Contradictions of Policy Discourse. In P. Haslam, J. Schafer, \& P. Beaudet (2008). An Introduction to International Development. Oxford, U.K.: Oxford University Press.

Malhotra, K. (2000). Educational Priorities and Challenges in the Context of Globalization, Prospects, 30 (3), $363-71$.

Mazrui, A.M., (2004). English in Africa: After the Cold War, London: Multilingual Matters. 200 
McGinn, N. (2005). The Sachs' ideas in the context of development history. Norrag News, 36, 22- 24.

Mickelson, R. A., Nkomo, M., \& Smith, S. S. (2001). Education, Ethnicity, Gender, and Social Transformation in Israel and South Africa, Comparative Education Review, 45 (1), 1 - 35.

Morris, P. (1996). Asia's Four Little Tigers: A Comparison of the Role of Education in their Development, Comparative Education, 32 (1), 95 - 109.

Mundy, K., \& Murphy, L. (2001). Transnational Advocacy, Global Civil Society? Emerging Evidence from the Field of Education, Comparative Education Review, 45 (1), 85 - 126.

Nordtveit, B. J. (2008). Education and sustainable growth in Africa: Following the path of a Beijing consensus. Norrag News, 40, 95-97.

Norman, D. (2004). Making targets work in education: The role of civil society. Norrag News, 33, 46-47, 48.

Odora-Hoppers, C. A. (2002). Indigenous knowledge and the integration of knowledge systems. Claremont, Cape Town: New Africa Books.

Reagan, T. and Mahwah, N. (2000). Non-Western Educational Traditions: Alternative Approaches to Educational Thought and Practice. New Jersey: Lawrence Erlbaum Associates.

Rose, P., (2005). Is there a 'fast-track' to achieving education for all? International Journal of Educational Development $25,381-394$

Rose, P. (2004). Tracking progress in the fast track initiative. Norrag News, 33, 31.

Rose, P. (2005). National and international development targets in education: Help or hindrance. Norrag News, $36,77-78,79$.

Rostow, W. W. (1960). The Stages of Economic Growth. London: Cambridge University Press.

Samoff, J. (2007). Education Quality: The disabilities of aid. International Review of Education, 53: 485-507.

Samoff, Joel. (2003). Institutionalizing International Influence. In R. F.Arnove \&

C.A. Torres (Eds.), ComparativeEducation: The Dialectic of the Global and the Local (Second Edition) Boulder: Rowman \& Littlefield.

Samoff, Joel. (1999a). Education Sector Analysis in Africa: Limited National Control and Even Less National Ownership. International Journal of Educational Development 19(4-5): 249-272.

Samoff, J. (1999b). Cooperation, But Limited Control and Little Ownership. Partnerships for capacity building and quality improvements in education. Paris: ADEA.

Samoff, J. (1996). Which Priorities and strategies for Education. Educational Development, 16, 3, pp. 249-271.

Smith, H. (2005). Ownership and capacity: Do current donor approaches help or hinder the achievement of international and national targets for education? International Journal of Educational Development, 25,445 .

Stromquist, N. P. (1998). The institutionalization of gender and its impact on educational policy, Comparative Education, 34 (1), 85 - 100.

Tabulawa, R. (2003). International Aid Agencies, Learner-centred Pedagogy and Political Democratisation: A critique. Comparative Education, 39 (1), 7 - 26.

Tabulawa, R. (1997). Pedagogical classroom practice and social context: The case of Botswana. International Journal of Educational Development, 17(2).

Takyi-Amoako, E. (2008). Globalization: An impediment to sustainable educational development in developing countries? Norrag News, 40, 52-53, 54.

Tikly, L. (2004). Education and the New Imperialism. Comparative Education, 40(2), 173 - 198.

Tilak, J. (2007). Rate of return to education: Best practice? Norrag News, 39, 83-86.

Villegas-Reimers, E. \& Reimers, R. (1996). Where are 60 Million Teachers? The Missing Voice in Educational Reforms. Prospects, XXVI (3), $469-492$.

Verger, A. \& Novelli, M. (2008). EFA and the global agenda for education and development: Addressing critical questions and omissions. Norrag News, 40, 145-147.

Webster, A. (1992). Introduction to the sociology of development (Second ed.). London: MacMillan Education LTD.

Welch, A. (1999). The Triumph of Technoracy or the Collapse of Uncertainty?: Modernity, postmodernity, and postcolonialism in comparative education. In R.F. Arnove and C.A. Torres (Eds.) Comparative Education: The dialectic of the global and the local. London: Rowan \& Littlefield.

Welch, A. (1993). Class, Culture and the State in Comparative Education: problems, perspectives and prospects. Comparative Education, 29 (1). 
Welch, Anthony R. (1985). The Functionalist Tradition and Comparative Education. Comparative Education, $21(1)$.

Welmond, M. (2002). Globalization Viewed from the Periphery: The Dynamics of Teacher Identity in the Republic of Benin. Comparative Education Review, 46 (1), 37 - 65.

Whitty, G., \& Power, S. (2000). Marketization and Privatization in Mass Education Systems, International Journal of Educational Development, 20 (2), 93 - 107.

Yamamoto, A. (2007). The end of poverty or the end of budget support? Norrag News, 39, 101-102.

Christian DaSilva is a $\mathrm{PhD}$ candidate in Education at the University of Ottawa. In addition to the impacts of development assistance on the education sector, his research interests include quality of education, and marginalized youth in Africa and Canada's Nunavut territory where he was formerly a techer and school superintendent. His $\mathrm{PhD}$ research examines EFA, declining primary enrolment, and quality of education issues in Tanzania. He can be reached at dasilva897@hotmail.com. 